\title{
Muslim Micro Entrepreneurs' Competency to Face Challenges in The Industrial Era 4.0
}

\author{
Royyan Ramdhani Djayusman ${ }^{1}$, Fajar Surya Ari Anggara ${ }^{2}$, Nur Hadi Ihsan ${ }^{3}$, \\ Dhika Amalia Kurniawan ${ }^{4}$ \\ \{royyan@unida.gontor.ac.id ${ }^{1}$, fajarsurya@unida.gontor.ac.id ${ }^{2}$, \\ nurhadiihsan@unida.gontor.ac.id ${ }^{3}$, dhika.amalia@unida.gontor.ac.id ${ }^{4}$ \} \\ University of Darussalam Gontor, Jalan Raya Siman, Ponorogo
}

\begin{abstract}
Micro Enterprises play a crucial role in contributing an economic development, particularly in East Java's economic prosperity. Nowadays, the rapid raising in Industry 4.0 is inevitable and put micro enterprises facing significant challenges and forced to push beyond the boundaries to sustain their competitive advantages and the competencies based on knowledge management to succeed as well. The competencies are integrated into an attempt to improve their business performance. In contrast, a study related to Micro Enterprise's competence in particular for the Indonesian Muslim Micro Enterprises is still very finite. Therefore, this paper explores some aspects of business competence they have in the current situation and another potential competency needed in facing a new revolution in the industrial era 4.0. Turning to the methodology used in this research, a quantitative approach utilized as a primary instrument in analyzing collected data from 250 respondents distributed in some districts in East Java Province such as Surabaya, Malang, Kediri, Ponorogo, Madiun and Ngawi. The respondents are the owner, manager, and owner-manager also. In addition, this study uses eleven aspects such as accounting, training on achievement motivation, business feasibility study, business plan, finance, human resource management, the use of accounting information and communication technology, leadership training, marketing and promotion, operational/ manufacturing management, and business research development to identify the core competency from Muslim micro enterprises. This research contributes to the recent description of Muslim micro enterprises competence and future three years of training needed. Furthermore, the implications of this study and directions for future research are also discussed.
\end{abstract}

Keywords: microenterprises, competency, industry revolution 4.0.

\section{Introduction}

The raising of technology and human needs accelerates the rapid development of industries which fulfill the needs. It is witnessed that the industries change quickly and transform to the next step of revolution called 4.0.

As a consequence, this new era brings challenges in various fields including the aspects of knowledge, technology, economics, social and political. The benefits of which can be obtained is effectiveness and efficiency in every activity including business in terms of time, cost, human resources and use of natural resources [1]. Also, the business world requires its human capital to be able to adjust the existing developments, especially in the aspects of mastering technology in their business operations. By doing this, the existing businesses could be 
improved and even more advanced. On the other hand, the downsides of this revolution could be harmful to entrepreneurs who are not capable in utilizing technology and unable to compete in the market places due to the lack of skills needed to measure the issues. Therefore, the inevitable raising of technology and industry should be faced by preparing human resource based on knowledge management and entrepreneurial competencies.

MSMEs contributes an essential role in the development of the Indonesian economy. It is obviously can be seen from its contribution to Gross Domestic Product (GDP) of the country which was around 60\% in both period 2011 and 2012 [2]. Besides, this type of enterprises has potential impact in creating a large proportion of jobs due to its endeavor to the job vacancies around $97 \%$ of the total workers in the national level, particularly in the retail sectors such as foods, beverages, and tobaccos. MSMEs have an essential influence in dropping the unemployment rate in Indonesia [3]. It indicates that the MSMEs have significant upsides in dealing with the unemployment issues in the nation. Therefore, the existence of MSMEs is essential to accomplish the national economic targets, in particular, in the East Java province.

In the East Java case, based on the data presented by Central Bureau for Statistics, there were 9.59 million people of significant scale to microscale business people out of a total population of 39.2 in 2018 and can contribute $74.36 \%$ of Gross Regional Domestic Product (GRDP) of the province. It indicates that business activities mainly micro-enterprises play an essential role as an economic driver in the region. In this case, micro-entrepreneurs especially Muslim micro-entrepreneurs have several challenges to compete for other larger business scale with the competencies they currently have mastered. Therefore, it is necessary to identify competencies possessed by Muslim micro entrepreneurs in dealing with industrial revolution 4.0 challenges.

Based on the discussion above, this research will articulate the entrepreneurial competencies among Muslim micro-entrepreneurs in the East Java province. This study is encouraged by the need to assess the level of entrepreneurial competency to face challenges of the industrial era 4.0. In general, the objective of this paper is to explore further information related to the readiness of Muslim micro entrepreneurs with their competencies in facing the challenges. By doing this, perhaps the observed identification can be utilized in initiating government policies and programmes related to the issue.

\section{Literature Review}

The business sector was placed in the second rank after manufacture based on the total research conducted about the industry 4.0 challenges [4]. It indicates that the business sector has an essential impact on the development of technologies and industries in the future. Hence, many experts defined several competencies that should be improved in an attempt to achieve better business performance in the inevitable industry revolution. The most convincing way in understanding the relationship between competency and business performance is its positive impact. For this purpose, All managerial competency dimensions such as technical, generic and conceptual skills had a significant influence on small business growth [5]. Also, The importance of entrepreneurial competencies for business performance based on the conceptual framework [6].

Furthermore, the management model of micro enterprises which adopted the corporate management aspects such as production, human resource, finance, and marketing [7]. The owners of SMEs realized the importance of the implementation of strategic planning, decision 
making, evaluation and control in their business management [8]. A study conducted by Li fond empirical evidence that business owner commonly has a higher level of entrepreneurial competencies compared to the managers and their entrepreneurial competency level could categorize both [9]. It means that both theoretical and practical issues support the importance of competency particularly knowledge management in business sustainability. Therefore, competency should be a crucial factor in developing businesses.

Another important competency is information technology. Digital marketing strategy has a significant implication about 78 percent on the SMEs competitiveness [10]. In contrast, MSMEs are not familiar with social media as the medium of business, in particular, marketing purposes due to the lack of technological skill [11]. Even though they were poor in this skill, but they showed great interest in using social media for marketing their products. It indicates that they need information technology skill to develop their enterprises. Therefore, this kind of competency is extremely required for improving MSMEs competitiveness in the foreseeable future.

Eventually, a study concerned on competitiveness conducted by Yeh and Chang examined six competencies; opportunity exploration, opportunity exploitation, organizing, strategic, relationship, and commitment competencies among micro-enterprises in Taiwan [12]. Besides, Lantu determined six main variables that shape the competitiveness of MSMEs; resource availability and business environment, business capability, policy and infrastructures, research and technology, financing and partnership, and performance [13]. Hence, the existence of competency and its correlation with competitiveness is one of the primary issues discussed in many academic papers and seminars.

\section{Research Method}

The objective of the study is to assess the level of entrepreneurial skills among Muslim micro entrepreneurs in East Java Province (Ponorogo, Madiun, Mantingan-Ngawi, Kediri, Surabaya, Malang). Due to the objective, descriptive research has been carried out. The data was from both primary as well as secondary sources. The former was collected through a structured questionnaire. The items included in the questionnaire were based on the previous surveys conducted by various researchers. Probing questions were also part of the instrument used.

The population of this research covered the enterprises in the province which mounted 250 micro-entrepreneurs, selected randomly formed the sample for the study. Questionnaires were distributed to all the respondents, even though three respondents provided incomplete data. To deal with this issue, the missing data was corrected by imputing missing data through statistics tool package. By doing this, the final respondent number that was considered for the result remains 250 .

The collected data were tabulated using Microsoft Excel spreadsheet with appropriate coding. Also, the data were also analyzed using Microsoft Excel and SPSS 20. The entrepreneurship competency of Muslim micro-entrepreneurs was assessed using the different type of competencies including accounting, business motivation, business feasibility study, business plan, financial management, human resource management, information and communication technology, leadership, marketing and promotion, operational / manufacturing management, and business research development. 


\section{Result and Discussion}

Identifying the competence of Muslim micro entrepreneurs is conducted by using eleven types of competencies inquired to the respondents. The previous literature related to entrepreneurial skills designed those eleven competencies. By asking any kinds of training joined and involved from both government and non-government organizations in the following competencies: accounting, business motivation, business feasibility study, business plan, financial management, human resource management, information and communication technology, leadership, marketing and promotion, operational / manufacturing management, and business research development.

\subsection{Accounting competency}

Table 1. Accounting competency

\begin{tabular}{lcc}
\hline & Frequency & Percent (\%) \\
\hline Yes & 40 & 16 \\
No & 210 & 84 \\
Total & $\mathbf{2 5 0}$ & $\mathbf{1 0 0}$ \\
\hline
\end{tabular}

Presented in Table 1 is the accounting competency from Muslim micro entrepreneurs. It is witnessed that the majority of respondents ( 84 percent) have not any skills related to the accountancy. It is proved that they have not received any pieces of training and education regarding this issue. Additionally, this also means that their ability to run the business based on the accounting principle is low which is only 16 percent of them who applied accounting system in doing their business. Therefore, Muslim micro-entrepreneurs are still lack of accounting competency.

\subsection{Business motivation competency}

Table 2. Business motivation competency

\begin{tabular}{lcc}
\hline & Frequency & Percent (\%) \\
\hline Yes & 58 & 23.2 \\
No & 192 & 76.8 \\
Total & $\mathbf{2 5 0}$ & $\mathbf{1 0 0}$ \\
\hline
\end{tabular}

Table 2 informs the business motivation competency of Muslim micro entrepreneurs. This competency is essential to face challenges in industry revolution 4.0. Also, it is also the main factor for entrepreneurs to survive in their business activities. It is seen that the majority of them (76.8 percent) do not have business motivation. It indicates that most of the respondents have a potential weakness which harms the sustainability of their business. By contrast, it is only about one-fifth of them who have the business motivation.

Regarding this issue, it would be the benefit to look the reason behind this fact deeply. Another assumption could be inquired such as the current businesses are categorized as a primary business or as secondary or only as a side job initiated by females besides their primary task as household managers. Therefore, motivation is a crucial factor in the sustainability of enterprises mainly micro-enterprises. 


\subsection{Business feasibility study competency}

Table 3. Business feasibility study competency

\begin{tabular}{lcc}
\hline & Frequency & Percent (\%) \\
\hline Yes & 58 & 23.2 \\
No & 192 & 76.8 \\
Total & $\mathbf{2 5 0}$ & $\mathbf{1 0 0}$ \\
\hline
\end{tabular}

It is observed from Table 3 about the competency on the business feasibility study that the majority of the Muslim micro-entrepreneurs (76.8 percent) do not have any feasibility study competency on their proposed business. It explains that most of them established their start-up without any valid and sufficient information supporting their business project. Market analysis, production, and promotion cost estimation are essential to start every business. Hence, it can be concluded that business feasibility competence has a significant impact on business performance due to its profit and marketing potency.

\subsection{Business plan competency}

Table 4. Business plan competency

\begin{tabular}{lcc}
\hline & Frequency & Percent (\%) \\
\hline Yes & 51 & 20.4 \\
No & 199 & 79.6 \\
Total & $\mathbf{2 5 0}$ & $\mathbf{1 0 0}$ \\
\hline
\end{tabular}

According to Table 4, the business plan competency is still low which is only 20.4 percent or around one-fifth of respondents who knew and practiced planning in starting and operating their business projects. In contrast, a massive number of them claimed that they do not have any skills in planning their business activities. It indicates that Muslim micro entrepreneurs operated their business with no standards and targets. As a consequence, the development of their businesses could be slow and difficult.

\subsection{Financial management competency}

Table 5. Financial management competency

\begin{tabular}{lcc}
\hline & Frequency & Percent (\%) \\
\hline Yes & 52 & 20.8 \\
No & 198 & 79.2 \\
Total & $\mathbf{2 5 0}$ & $\mathbf{1 0 0}$ \\
\hline
\end{tabular}

Table 5 articulates the financial management competency among the respondents. It is witnessed that most of them (79.2 percent) do not have this kind of competency. It explains that the majority of respondents could not manage their business finance. It may cause a lack of capital and unclear financial statement as well. Therefore, many microenterprises are not bankable due to their inability to explaining their business financial condition throughout 
financial reports. Not only will this competency cause limited access to conventional financial institutions, but also access to the Islamic financial ones.

\subsection{Human resource management competency}

Table 6. Human resource management competency

\begin{tabular}{lcc}
\hline & Frequency & Percent (\%) \\
\hline Yes & 44 & 17.6 \\
No & 206 & 82.4 \\
Total & $\mathbf{2 5 0}$ & $\mathbf{1 0 0}$ \\
\hline
\end{tabular}

Presented in Table 6 the competence of human resource management from the Muslim micro entrepreneurs. It can be seen that less than one-fifth or around 17.6 percent of respondents are capable of managing human resources in their enterprises. It means that the level of competency is low. In other explanation, it is observed that the majority of them about 82.4 percent do not have any abilities in human resource management. Also, it can be explained that most of them could not arrange potential staffs or even unable to develop their business due to the lack of this skill.

\subsection{Information and communication technology competency}

Table 7. Information and communication technology competency

\begin{tabular}{lcc}
\hline & Frequency & Percent $(\boldsymbol{\%})$ \\
\hline Yes & 50 & 20 \\
No & 200 & 80 \\
Total & $\mathbf{2 5 0}$ & $\mathbf{1 0 0}$ \\
\hline
\end{tabular}

Based on the presented data in Table 7 , it is easily understood that the majority of respondents ( 80 percent) are illiterate in the term of information and communication technology. Only a few of them around one-fifth have been familiar with this advanced technology in operating their businesses. It illuminates that most of the Muslim microentrepreneurs are not competent in using both information and communication technologies, in particular, for developing their business performance and marketing as well. Besides, most of them are much more familiar with the traditional method in the way of marketing and communicating with customers.

\subsection{Leadership competency}

Table 8. Leadership competency

\begin{tabular}{lcc}
\hline & Frequency & Percent (\%) \\
\hline Yes & 54 & 21.6 \\
No & 196 & 78.4 \\
Total & $\mathbf{2 5 0}$ & $\mathbf{1 0 0}$ \\
\hline
\end{tabular}

Regarding leadership competency, Table 8 articulates the percentage from the respondents who declared that they have leadership competency. It is fond that only about 
one-fifth from the respondents who have this type of competency, while it is around 78.4 percent of them who are lack of these skills particularly in doing their business. It could be possible that the number and the type of staffs may effect the level of leadership.

\subsection{Marketing and promotion competency}

Table 9. Marketing and promotion competency

\begin{tabular}{lcc}
\hline & Frequency & Percent (\%) \\
\hline Yes & 71 & 28.4 \\
No & 179 & 71.6 \\
Total & $\mathbf{2 5 0}$ & $\mathbf{1 0 0}$ \\
\hline
\end{tabular}

Based on Table 9 above, it is observed that the majority of Muslim micro-entrepreneurs (71.6 percent) are incompetent in marketing and promoting their products. It is about 28.4 percent who are capable of doing their business through marketing and promotion activities. It indicates that most of them could not develop their businesses due to the lack of marketing and promotion skills. Also, to face industrial revolution 4.0 analyzing the market and mastering it should be the primary consideration for every enterprise. Hence, most of the respondents would meet a big challenge in the marketing and promotion of their products.

\subsection{Operational and manufacturing management competency}

Table 10. Operational and manufacturing management competency

\begin{tabular}{lcc}
\hline & Frequency & Percent (\%) \\
\hline Yes & 34 & 13.6 \\
No & 216 & 86.4 \\
Total & $\mathbf{2 5 0}$ & $\mathbf{1 0 0}$ \\
\hline
\end{tabular}

Based on Table 10, it can be seen that the operational and manufacturing management competency among the respondents is still low. It is proven from the fact that only around one-tenth (13.6 percent) of them who could manage their business operation and manufacture, whereas about 86.4 percent of them are not able to measure this issue. Therefore, practical issues in corporate management such as operational and manufacturing managerial skills should be another critical consideration in operating businesses.

\subsection{Research and business development competency}

Table 11. Research and business development competency

\begin{tabular}{lcc}
\hline & Frequency & Percent (\%) \\
\hline Yes & 36 & 14.4 \\
No & 214 & 85.6 \\
Total & $\mathbf{2 5 0}$ & $\mathbf{1 0 0}$ \\
\hline
\end{tabular}

Presented information from Table 11 shows the research and business development competency among the respondents. It is observed that the majority of them (85.6 percent) could not develop their business based on research and development approaches. It means that most of the respondents are doing and expanding their business without research and business 
development due to the lack of this type of skills. It would be somewhat tricky for micro enterprises to increase their business performance in the industrial revolution of 4.0.

\section{Conclusion}

Majority of Muslim micro Enterprises in East Java (around 81\%) do not yet have competence in 11 aspects examined. It is observed that the lowest competence they have is operational and manufacturing management competency at 13.6 percent, followed by research and business development at 14.4 percent. Furthermore, it is found that marketing and promotion competency is placed on the top competencies which are at 28.4 percent, followed by business motivation and leadership at 23.2 and 21.6 percent respectively. Eventually, overall, this study indicates that Muslim micro Enterprises in East Java need to improve those competencies in an attempt to face the challenges of the era of industrial revolution 4.0.

\section{References}

[1] K. Zhou, T. Liu, and L. Zhou, "Industry 4.0: Towards Future Industrial Oppotunities and Challenges," in 2015 12th International Conference on Fuzzy Systems and Knowledge Discovery (FSKD 2015), 2015, no. August, pp. 2147-2152.

[2] Lembaga Pengembangan Perbankan Indonesia, Profil Bisnis UMKM LPPI. Jakarta: LPPI dan Bank Indonesia, 2015.

[3] R. Hafni and A. Rozali, "Analisis Usaha Mikro, Kecil, dan Menengah (umkm) terhadap Penyerapan Tenaga Kerja di Indonesia," Ilmu Ekon. dan Stud. Pembang., vol. 15, no. 2, pp. 77-96, 2017.

[4] H. Prasetyo and W. Sutopo, "INDUSTRI 4.0: TELAAH KLASIFIKASI ASPEK DAN ARAH PERKEMBANGAN RISET,” J@ ti Undip J. Tek. Ind., vol. 13, no. 1, pp. 17-26, 2018.

[5] S. Sidek and M. R. Mohamad, "Managerial Competencies and Small Business Growth: Empirical Evidence From Microfinance Participants," Int. J. Manag. Sci., vol. 21, no. 1, pp. 39-59, 2014.

[6] S. Tehseen and T. Ramayah, "Entrepreneurial Competencies and SMEs Business Success: The Contingent Role of External Integration," Mediterr. J. Soc. Sci., vol. 6, no. 1, pp. 50-61, 2015.

[7] L. Bismala, "Model Manajemen Usaha Mikro Kecil dan Menengah (UMKM) untuk Meningkatkan Efektivitas Usaha Kecil Menengah,” J. Entrep. dan Entrep., vol. 5, no. 1, pp. 19-26, 2016.

[8] E. Suyono, "Pentingnya Sistem Pengendalian Manajemen dalam Pengelolaan Usaha Kecil dan Menengah di Kabupaten Banyumas, Jawa Tengah," Kompartemen J. Ilm. Akunt., vol. 16, no. 1, pp. 64-83, 2018.

[9] Xiang Li, "Entrepreneurial competencies as an entrepreneurial distinctive: An examination of the competency approach in defining entrepreneurs," Singapore Management University, 2009.

[10] A. Wardhana, "Strategi Digital Marketing Dan Implikasinya Pada Keunggulan Bersaing Ukm Di Indonesia," in Forum Keuangan dan Bisnis, 2015, vol. IV, no. August, pp. 327-337.

[11] S. Purwana ES, Dedi, Rahmi, Aditya, "Pemanfaatan Digital Marketing Bagi Usaha Mikro , Kecil , Dan Menengah ( Umkm ),” J. Pemberdaya. Masy. Madani, vol. 1, no. 1, pp. 1-17, 2017.

[12] T.-J. Yeh and H.-J. Chang, "A Multi-Case Study of Entrepreneurial Competencies in Microenterprises,” Int. J. Manag. Econ. Soc. Sci., vol. 7, no. 4, pp. 321-346, 2018.

[13] D. C. Lantu, M. S. Triady, A. F. Utami, and A. Ghazali, "Pengembangan Model Peningkatan Daya Saing UMKM di Indonesia: Validasi Kuantitatif Model," J. Manaj. Teknol., vol. 15, no. 1, pp. 77-93, 2016. 
